CZASOPISMO INŻYNIERII LĄDOWEJ, ŚRODOWISKA I ARCHITEKTURY JOURNAL OF CIVIL ENGINEERING, ENVIRONMENT AND ARCHITECTURE JCEEA, t. XXXIII, z. 63 (2/I/16), kwiecień-czerwiec 2016, s. 307-320

\author{
Tomasz SIWOWSKI ${ }^{1}$
}

Mateusz RAJCHEL ${ }^{2}$

\title{
KSZTAŁTOWANIE MOSTOWYCH DŹWIGARÓW HYBRYDOWYCH TYPU „KOMPOZYT FRP - BETON”
}

\begin{abstract}
Pomimo wielu przewag w stosunku do konwencjonalnych materiałów budowlanych, współczesny rozwój zastosowań kompozytów FRP w budownictwie mostowym jest ograniczony ze względu na wysoki koszt początkowy oraz zbyt małą sztywność elementów konstrukcyjnych. W celu redukcji tych ograniczeń od blisko 20 lat w wielu krajach testuje się rozwiązania mieszane (hybrydowe), łączące kompozyty FRP z konwencjonalnymi materiałami budowlanymi, w tym głównie $\mathrm{z}$ betonem. Kształtowanie konstrukcji hybrydowej, bazujące na właściwościach poszczególnych materiałów składowych, ma na celu zwiększenie sztywności i redukcję kosztów, bez utraty nośności, lekkości i łatwości budowy mostów z takich dźwigarów. W artykule przedstawiono ewolucję w kształtowaniu hybrydowych dźwigarów mostowych typu „kompozyty FRP - beton” na przestrzeni ponad 20 lat. Podano także podstawowe zasady kształtowania dźwigarów hybrydowych, wynikające z przeprowadzonej analizy, a także wskazano kierunki dalszych badań, niezbędnych w celu upowszechnienia tych innowacyjnych konstrukcji mostowych.
\end{abstract}

Słowa kluczowe: dźwigar hybrydowy, kompozyt FRP, płyta betonowa, kształtowanie, most drogowy

\section{Wprowadzenie}

Jednym z głównych problemów budownictwa mostowego jest znacząca redukcja trwałości konstrukcji mostowych spowodowana korozją stali i betonu. Zjawisko to jest potęgowane przez stosowanie soli do zwalczania śliskości dróg, jak to ma miejsce w Polsce i w krajach o podobnym klimacie. W konsekwencji prowadzi to zazwyczaj do konieczności przedwczesnego generalnego remontu i/lub wymiany (przebudowy) całego mostu. Jednym ze współczesnych rozwiązań tego problemu jest zastosowane do budowy mostów kompozytów konstrukcyjnych FRP (fibre reinforced polymers). Kompozyty FRP dzięki swoim dosko-

\footnotetext{
${ }^{1}$ Autor do korespondencji: Tomasz Siwowski, Politechnika Rzeszowska, Al. Powstańców Warszawy 12, 35-959 Rzeszów, (17) 8651 596, siwowski@prz.edu.pl

2 Mateusz Rajchel, Politechnika Rzeszowska, Al. Powstańców Warszawy 12, 35-959 Rzeszów, (17) 8651 596,mrajchel@ prz.edu.pl
} 
nałym właściwościom, jak duża wytrzymałość, wysoka trwałość i odporność na korozję oraz mały ciężar (lekkość), stają się współcześnie pełnoprawnym, obok betonu i stali, materiałem konstrukcyjnym, branym pod uwagę przy projektowaniu i budowie mostów [1].

Jednakże pomimo wielu przewag w stosunku do konwencjonalnych materiałów budowlanych, współczesny rozwój zastosowań kompozytów FRP w budownictwie mostowym jest ograniczony do dwóch obszarów: napraw i wzmocnień konstrukcji istniejących oraz wymiany żelbetowych płyt pomostowych. Głównym powodem tak ograniczonego zastosowania jest wysoki koszt początkowy kompozytów, zbyt mała sztywność elementów konstrukcyjnych, wykonywanych głównie z kompozytów na bazie włókien szklanych (GFRP - glass fibre reinforced polymers), a także nagła postać zniszczenia kompozytu, niedopuszczalna w konstrukcjach budowlanych. Podczas gdy problem wysokiej ceny początkowej może zostać wkrótce rozwiązany za pomocą masowej i zautomatyzowanej produkcji przemysłowej elementów kompozytowych, tak problem braku sztywności i bezpiecznej postaci zniszczenia może być rozwiązany jedynie przez innowacyjne rozwiązania projektowe [2].

W celu redukcji wymienionych ograniczeń, od blisko 20 lat w wielu krajach testuje się rozwiązania mieszane (hybrydowe), łączące w jednej konstrukcji kompozyty FRP z konwencjonalnymi materiałami budowlanymi, w tym głównie $\mathrm{z}$ betonem. Konstrukcja dźwigara hybrydowego składa się z belki kompozytowej o przekroju dwuteowym, skrzynkowym (jedno- lub wielokomorowym) lub okrągłym oraz z płyty betonowej, która pełni rolę pomostu obiektu mostowego. Sztywne zespolenie obu tych elementów ma na celu zapewnienie ich współpracy przy przenoszeniu obciążeń. Głównym celem tworzenia konstrukcji hybrydowych jest takie połączenie różnych materiałów, aby każdy z nich był użyty w sposób wykorzystujący w optymalnym stopniu jego najlepsze właściwości. Dlatego w dźwigarach hybrydowych różne materiały konstrukcyjne są stosowane do przeniesienia rozciągania, ściskania i ścinania, generowanego w obciążonej konstrukcji.

Optymalizacja konstrukcji hybrydowej bazująca na właściwościach poszczególnych materiałów składowych, ma głównie na celu uzyskanie wymaganej nośności i sztywności oraz bezpiecznej postaci zniszczenia przy jednoczesnej redukcji zużycia droższych materiałów. Oczekuje się także, że wykorzystanie nowych, zaawansowanych technologicznie materiałów kompozytowych w budownictwie mostowym, doprowadzi do szybszej budowy i mniejszych zakłóceń ruchu drogowego dzięki lekkości i łatwości budowy mostów z tego materiału. Dzięki wysokiej trwałości kompozytów i związanym z tym ograniczeniem niezbędnych działań utrzymaniowych, mniejszy będzie także koszt kompozytowych obiektów mostowych, liczony w cyklu życia (LCC). Wreszcie ograniczone wymiary takich dźwigarów, dzięki wysokiej wytrzymałości kompozytu, wpływają korzystnie na estetykę mostu. 
Wstępne prace badawcze oraz pierwsze, prototypowe aplikacje wykazały, że połączenie kompozytów FRP z betonem jest bardzo efektywnym rozwiązaniem konstrukcyjnym dla drogowych obiektów mostowych [3], [4]. W artykule przedstawiono ewolucję w kształtowaniu mostowych dźwigarów hybrydowych typu ,kompozyty FRP - beton” na przestrzeni ponad 20 lat oraz ich wybrane zastosowania w przęsłach obiektów mostowych. Na podstawie analizy stosowanych rozwiązań konstrukcyjnych sformułowano podstawowe zasady kształtowania dźwigarów hybrydowych z przeznaczeniem do budowy mostów drogowych. W podsumowaniu podano kierunki dalszych badań własnych, niezbędnych w celu upowszechnienia tych innowacyjnych, zaawansowanych technologicznie oraz spełniających zasady zrównoważonego rozwoju konstrukcji mostowych.

\section{Ewolucja w kształtowaniu dźwigarów hybrydowych}

Pierwsze dźwigary hybrydowe typu „kompozyt FRP - beton” były wykonywane na bazie stosunkowo niewielkich kształtowników z kompozytów szklanych (GFRP) o przekroju skrzynkowym, które w strefie górnej (ściskanej) łączono z płytą betonową, a w strefie dolnej (rozciąganej) wzmacniano dodatkowo laminatem z kompozytu węglowego CFRP (carbon fibre reinforced polymers) (rys.1). Kształtowniki były wykonywane metodą pultruzji, dlatego wymiary ich przekrojów poprzecznych nie były duże.

a)

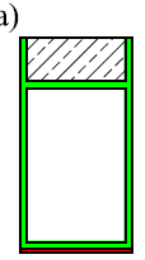

d)

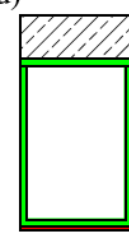

GFRP b)

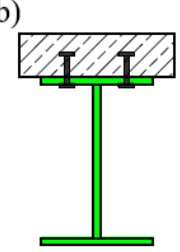

e)

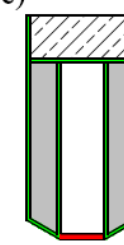

c)

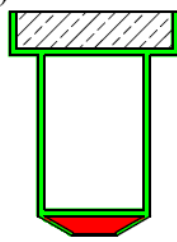

f)

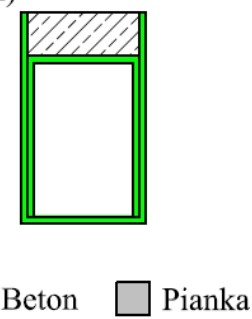

Rys. 1. Kształt i budowa pierwszych dźwigarów hybrydowych typu „kompozyt FRP - beton”

Fig. 1. Shape and structure of first hybrid girders made of FRP composites and concrete 
Pierwszy taki dźwigar hybrydowy (rys.1a) zaprojektowano i poddano badaniom w 1992 r. w USA. Dla uzyskania współpracy kompozytu i betonu użyto sworzni stalowych. Podczas badań pod obciążeniem statycznym przy maksymalnym obciążeniu jako pierwszy zerwaniu ulegał laminat CFRP, a następnie przy rosnącym obciążeniu nastąpiło zmiażdżenie betonu w strefie ściskanej [5]. Taka forma pracy i zniszczenia dźwigara została scharakteryzowana jako swoista ,pseudo-plastyczność”, pozwalająca na wczesne „ostrzeganie” przed nagłym zniszczeniem dźwigara, charakterystycznym dla konstrukcji w pełni kompozytowej. Jest to jedna $\mathrm{z}$ charakterystycznych cech dźwigarów hybrydowych, potwierdzona także w kolejnych badaniach [6], [7]. Bardzo podobny dźwigar był przedmiotem badań i późniejszego wdrożenia w Australii [8]. Belka o przekroju skrzynkowym, wykonana z kompozytu GFRP, została wzmocniona w strefie ściskanej betonem, a w strefie rozciąganej laminatem CFRP (rys.1d). Celem obu wzmocnień było uzyskanie dużej sztywności dźwigara. Dźwigary o podobnym kształcie i konstrukcji były przedmiotem kolejnych badań opisanych w pracach [9], [10], [11], [12] (rys.1 c,e,f).

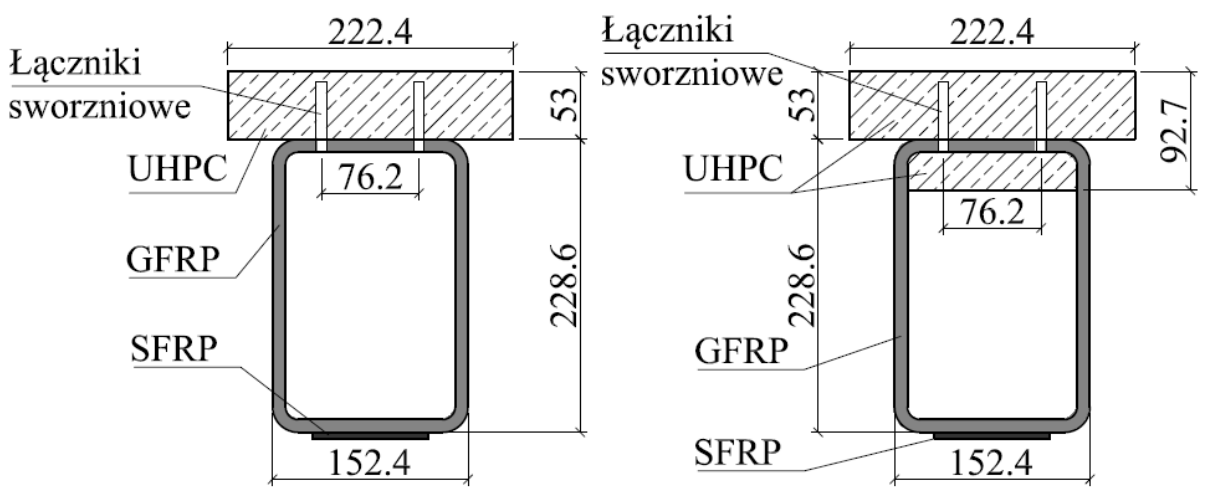

Rys. 2. Przekrój poprzeczny dźwigara hybrydowego wg [13]

Fig. 2. Cross-section of the hybrid girder according to [13]

W Kanadzie w 2007 r. opracowano dźwigar mostowy, bazujący na kompozytowym kształtowniku o zamkniętym przekroju skrzynkowym, złożony z kilku zaawansowanych technologicznie materiałów [13]. Podstawą dźwigara jest kształtownik skrzynkowy GFRP (rys.2). W jego górnej części zastosowano płytę wykonaną $\mathrm{z}$ ultrawytrzymałego betonu, zbrojonego włóknami stalowymi UHPSFRC (ultra-high-performance steel-fibre reinforced concrete). Płyta betonowa nadaje dźwigarowi wysoką sztywność i jednocześnie zabezpiecza ściskany pas belki kompozytowej przed wyboczeniem. Beton połączono z kompozytem za pomocą kleju epoksydowego oraz dodatkowo za pomocą sworzni kompozytowych o średnicy $9,5 \mathrm{~mm}$. W dolnej, rozciąganej części dźwigara zastosowano 
przyklejane od zewnątrz laminaty wykonane alternatywnie z kompozytu z włóknami stalowymi (SFRP- steel fibre reinforced polimer) lub z kompozytu węglowego CFRP. Na końcach dźwigara, w strefie podporowej, belka kompozytowa jest wypełniona betonem w celu wzmocnienia przekroju na ścinanie. W kolejnych modyfikacjach, dla zwiększenia nośności dźwigara zmieniono sposób połączenia betonu i kompozytu [14]. Górną powierzchnię belki GFRP dodatkowo uszorstniono pisakiem, wypełniającym klej epoksydowy oraz wprowadzono warstwę betonu do wewnątrz skrzynki, uzyskując w ten sposób możliwość zastosowania dłuższych sworzni kompozytowych (rys.2). Ta modyfikacja przyniosła oczekiwane rezultaty, zwiększając nośność dźwigara hybrydowego o kilkanaście procent.

Celem kolejnych prac badawczych nad kształtowaniem dźwigarów hybrydowych było wyeliminowanie głównych ograniczeń poprzednich rozwiązań [15]. W tym celu przekrój dźwigara, składający się z kształtownika GFRP, płyty $\mathrm{z}$ betonu oraz laminatu CFRP przyklejonego do spodu belki, owinięto w całości dodatkową matą kompozytową GFRP (rys.3). Warstwa zewnętrznego kompozytu GFRP ma podwójną rolę. Główną jej rolą jest zespolenie kształtownika GFRP i betonu, zapewnienie współpracy tych elementów oraz zabezpieczenie dźwigara przed przedwczesnym rozwarstwieniem. Drugą rolą tego kompozytu, który ma układ włókien pod kątem $45^{\circ}$ do osi podłużnej dźwigara, jest zwiększenie nośności na ścinanie kształtownika GFRP, który ma włókna jedynie w kierunku podłużnym (pultruzja).

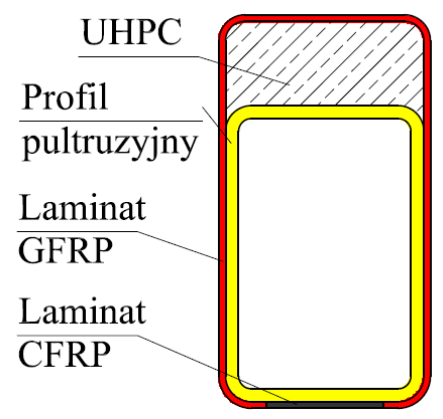

Rys. 3. Przekrój poprzeczny dźwigara wg [15]

Fig. 3. Cross-section of the girder according to [15]

Od początku XXI w. rozpoczęto badania i wdrażanie w mostownictwie dźwigarów hybrydowych, składających się z elementów kompozytowych o przekroju zamkniętym (rur okrągłych i prostokątnych), wypełnionych w całości betonem zwykłym lub lekkim (tzw. przekrój CFFT - concrete filled FRP tube). Elementy kompozytowe GFRP lub CFRP mogą być wykonywane nie tylko metodą pultruzji, lecz także metodą nawijania (filament winding). Dźwigary 
hybrydowe typu CFFT charakteryzują się doskonałym wykorzystaniem specyficznych właściwości każdego z użytych materiałów. Podczas gdy beton przenosi doskonale ściskanie oraz zabezpiecza ścianki rury kompozytowej przed niestatecznością miejscową, kompozyt ściśle zamykając beton zwiększa jego wytrzymałość i plastyczność, przenosi rozciąganie, i jednocześnie zabezpiecza beton przed agresywnym środowiskiem zewnętrznym.

Po raz pierwszy przekrój typu CFFT został wdrożony do budowy mostu w USA w 2002 r. [16]. Rura o średnicy wewnętrznej $340 \mathrm{~mm}$ i grubości ścianki 9,5 mm została wypełniona betonem lekkim. Na długości dźwigara znajdowały się elementy usztywniające (żebra), które zapewniały przeniesienie sił ścinających pomiędzy cienką powłoką kompozytową GFRP, a wypełniającym wewnętrzną przestrzeń betonem. W obiektach mostowych dźwigar CFFT był połączony z żelbetową lub kompozytową płytą pomostową za pomocą łączników, wykonanych z prętów zbrojeniowych, zatopionych w betonie (rys.4).
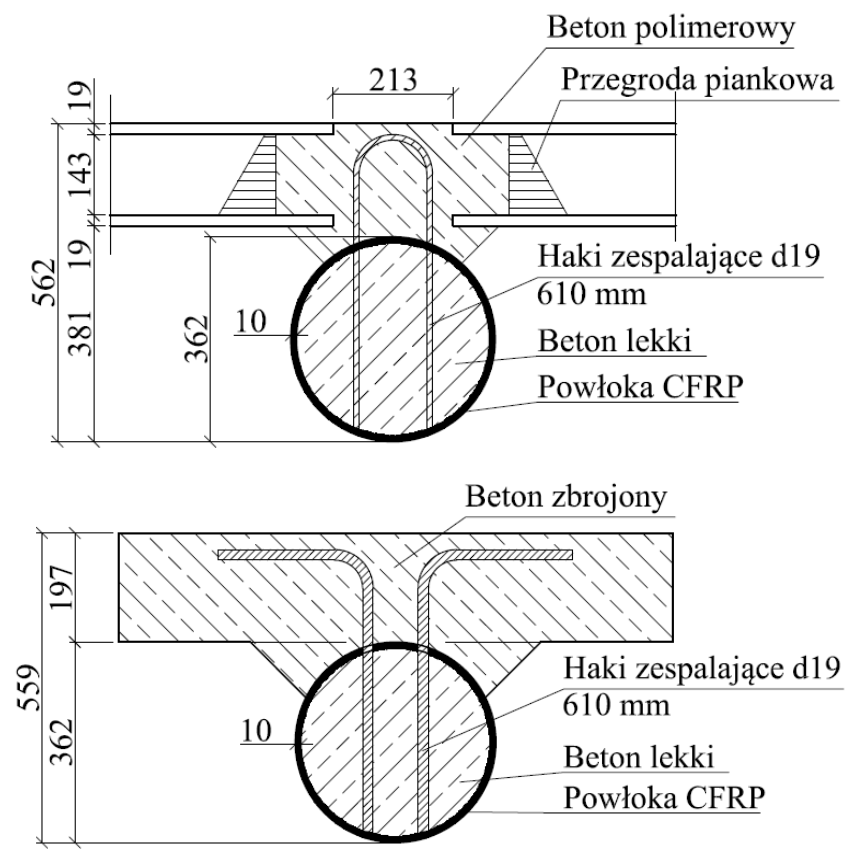

Rys. 4. Hybrydowe przekroje rurowe z płytą kompozytową (góra) i żelbetową (dół)

Fig. 4. CFFT cross-section with the FRP composite (upper) and concrete (bottom) deck slab

Kolejna forma mostowych dźwigarów hybrydowych składa się z trzech belek kompozytowych GFRP o kształcie trapezowym, wykonanych metodą nawijania i sklejonych razem (rys.5). W celu obniżenia sił ścinających pomiędzy belkami trapezowymi, pochylenie ich środników ustalono jako 3/8. Na belkach jest 
ułożona cienka płyta betonowa o grubości ok. $100 \mathrm{~mm}$ (max. 10\% wysokości dźwigara), a następnie cały układ jest owinięty zewnętrznym laminatem GFRP [17]. W celu zapewnienia współpracy betonu i kompozytu zastosowano łączniki z kształtowników GFRP, przyklejanych poprzecznie do belek. Po ułożeniu wszystkich trzech elementów (belki kompozytowe, beton, tkanina) całość połączono w dźwigar hybrydowy za pomocą infuzji VARTM (Vacuum Assisted Resin Transfer Molding) z wykorzystaniem żywicy poliestrowej. Beton zapewniał odpowiednią sztywność dźwigara, zabezpieczał górne płaszczyzny belek przed wyboczeniem oraz redukował lokalne oddziaływanie koła pojazdu na kompozyt.

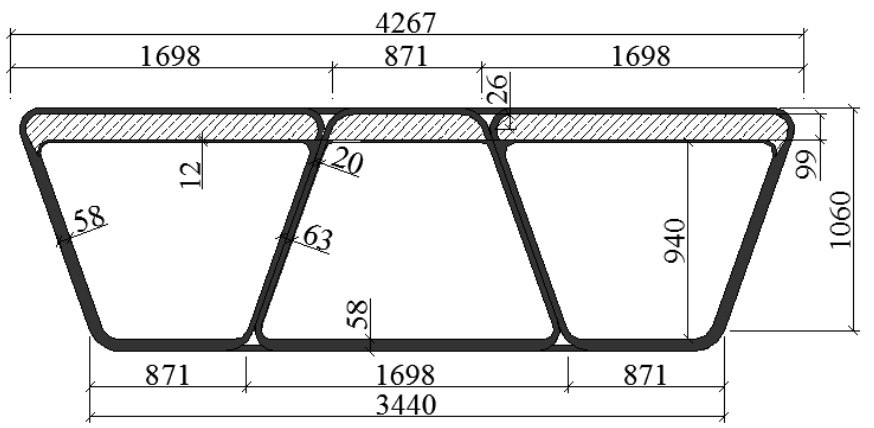

Rys. 5. Przekrój poprzeczny dźwigara wg [17]

Fig. 5. Cross-section of the girder according to [17]

Bardzo popularny w USA jest dźwigar hybrydowy, składający się z belki kompozytowej o przekroju U oraz płyty betonowej, zespolonej z belką za pomocą specjalnych łączników prętowych (rys.6). Belka kompozytowa GFRP jest wykonywana metodą laminowania ręcznego (hand lay-up). Belka do wysokości osi obojętnej jest wypełniana styropianem, który stanowi deskowanie tracone dla betonu płyty, wypełniającego górną (ściskaną) część belki. Belka kompozytowa jest połączona $\mathrm{z}$ betonem za pomocą poziomych łączników prętowych z rur stalowych o średnicy $48 \mathrm{~mm}$, zapewniających pełne zespolenie i współpracę obu elementów dźwigara hybrydowego [18].

Dźwigar pod rynkowa nazwą HCB (Hybrid Composite Beam) jest najbardziej złożonym przykładem połączenia różnych materiałów konstrukcyjnych w jednym dźwigarze hybrydowym w celu optymalnego wykorzystania ich cech materiałowych [19]. Dźwigar składa się z trzech głównych elementów: kompozytowej formy skrzynkowej z GFRP wypełnionej pianką o dużej gęstości, wewnętrznego łuku betonowego oraz stalowych prętów lub splotów (rys.7). Całość jest połączona wzajemnie w jednym procesie infuzji systemem VARTM. Do wykonania łuku wewnętrznego stosuje się beton samozagęszczalny. Łuk betonowy przenosi siły ściskające, a dolne zbrojenie stalowe przenosi rozciąganie wzdłuż pasa dolnego dźwigara hybrydowego. 


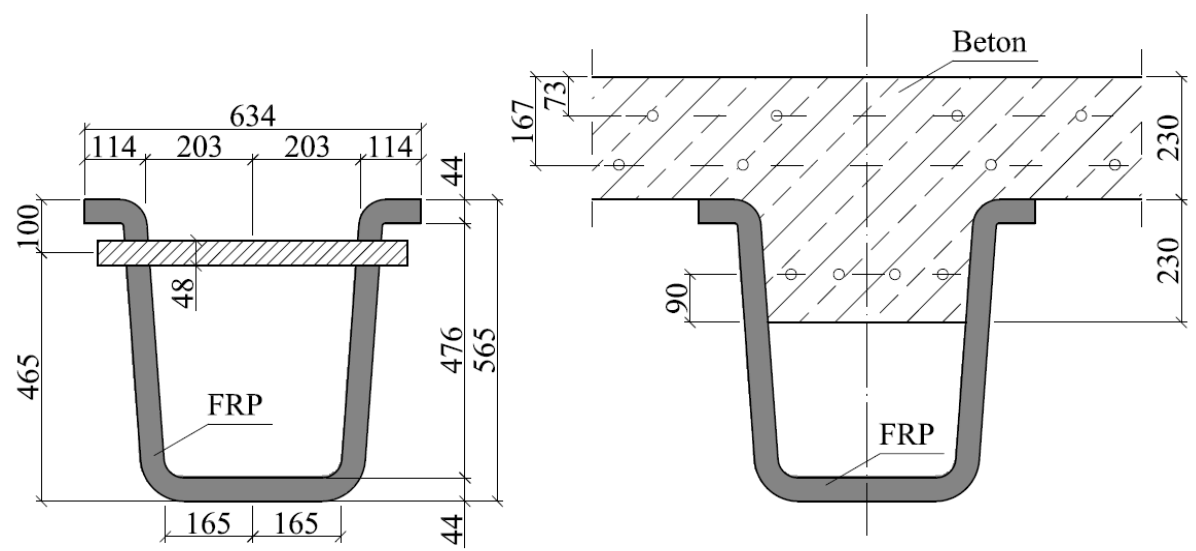

Rys. 6. Przekrój poprzeczny dźwigara U wg [18]

Fig. 6. Cross-section of the U girder according to [18]

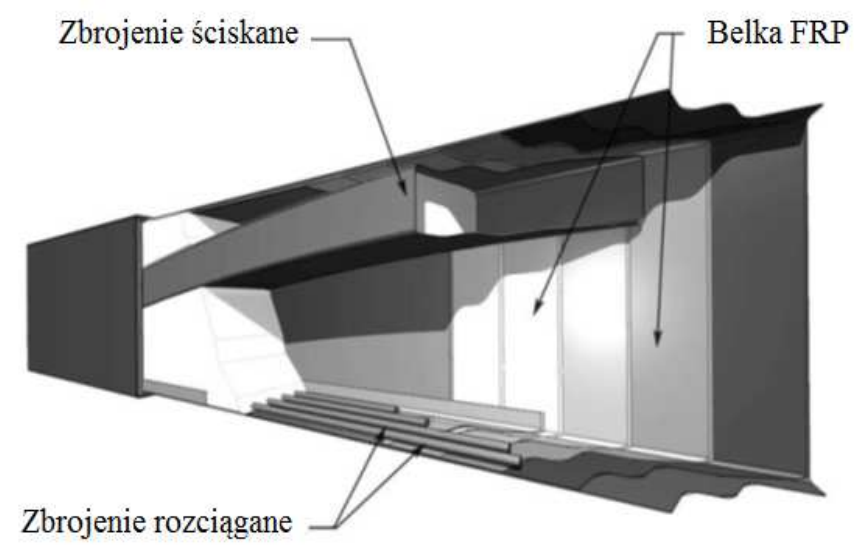

Rys. 7. Budowa dźwigara HBC wg [19]

Fig. 7. Structure of the HBC girder according to [19]

Pierwszym europejskim przykładem prac naukowo-badawczych, dedykowanych rozwojowi mostów kompozytowych, jest skrzynkowy dźwigar hybrydowy o przekroju zamkniętym, opracowany w 2008 r. Hiszpanii [20]. Dźwigar składa się z kompozytu wykonanego z tzw. prepregów CFRP, ułożonych na lekkim rdzeniu z pianki poliuretanowej (rys.8). Rdzeń, oprócz funkcji formy dla ukształtowania przekroju kompozytu, zapewnia także stateczność miejscową środników belki pod obciążeniem. Po ułożeniu prepregów na rdzeniu całość dźwigara jest poddawana procesowi infuzji VARTM. Dla przeniesienia sił ścinających przekroje podporowe belki zostały usztywnione wklejonymi przepo- 
nami z kompozytu CFRP. Zespolenie belki kompozytowej z płytą betonową wykonano za pomocą kształtowników GFRP o przekroju I 100 × 80 × $8 \mathrm{~mm}$, przyklejonych poprzecznie do górnej powierzchni belki. Płyta pomostu o grubości $20 \mathrm{~cm}$ jest wykonana $\mathrm{z}$ betonu zwykłego, zbrojonego prętami stalowymi o średnicy $16 \mathrm{~mm}$.

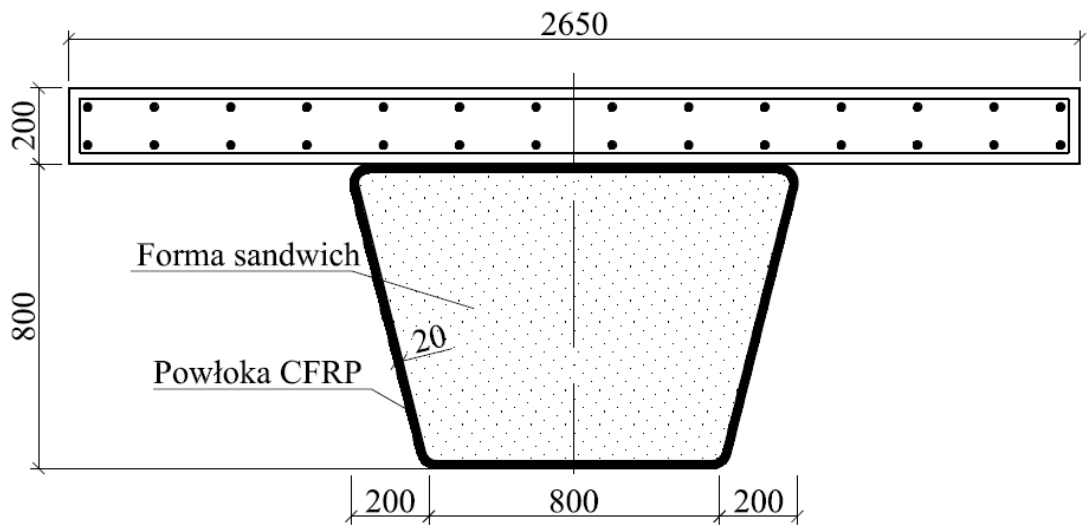

Rys. 8. Skrzynkowy dźwigar hybrydowy opracowany przez firmę Acciona wg [20] Fig. 8. Box hybrid girder developed by Acciona according to [20]

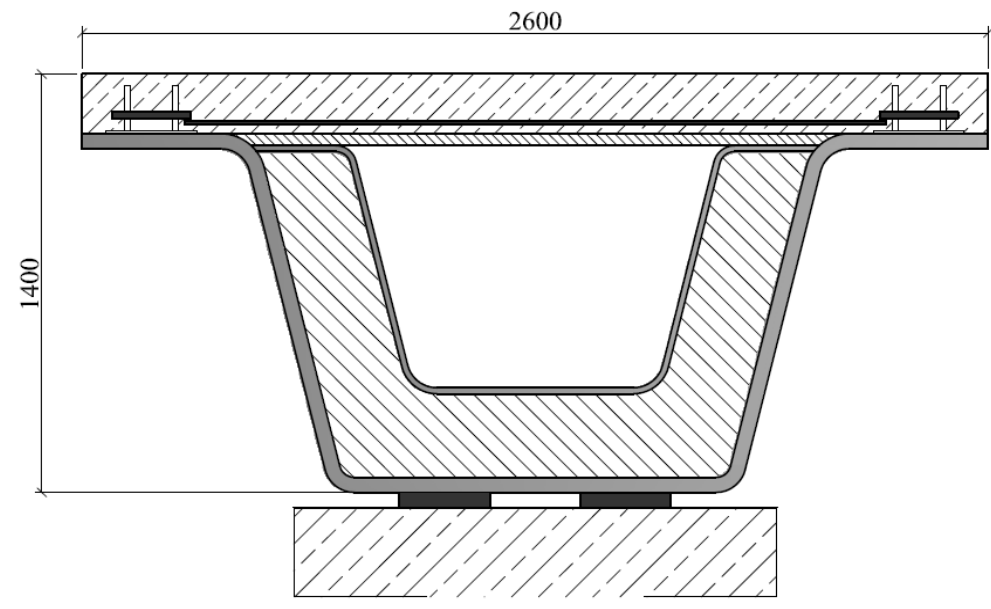

Rys. 9. Przekrój poprzeczny dźwigara wg [21]

Fig. 9. Cross-section of the girder according to [21]

Ponieważ koszt wykonania przedstawionego powyżej dźwigara okazał się dość wysoki, w kolejnym hiszpańskim projekcie badawczym zmieniono konstrukcję i metodę wytwarzania dźwigarów kompozytowych. Nową propozycją 
jest belka trapezowa, otwarta górą, wykonana z kompozytu mieszanego CFRP/GFRP na bazie żywicy epoksydowej w procesie infuzji VARTM (rys.9). Trapez zamykany jest od góry kompozytową płytą warstwową (typu sandwich), przyklejaną do pasów górnych belki, która stanowi deskowanie tracone dla żelbetowej płyty pomostu, zespolonej z belką kompozytową łącznikami sworzniowymi rozmieszczonymi wzdłuż pasów górnych belki [21]. Dla zwiększenia sztywności skrętnej dźwigara i zabezpieczenia środników przed wyboczeniem, na długości dźwigara wklejono wewnątrz sześć przepon. Do zespolenia belki kompozytowej i płyty betonowej użyto sworzni wykonanych z kompozytu GFRP. Także zbrojenie podłużne i poprzeczne betonowej płyty pomostu wykonane zostało z prętów kompozytowych GFRP. Taki dźwigar został wdrożony na kilku obiektach mostowych w Hiszpanii.

\section{Podstawowe zasady kształtowania mostowych dźwigarów hy- brydowych}

Przedstawiony przegląd obejmuje większość dźwigarów hybrydowych typu „kompozyt FRP - beton”, jakie w ciągu ostatnich 20 lat zostały opracowane, zbadane i wdrożone w mostach drogowych na świecie. Wyciągając wnioski z tego przeglądu należy zauważyć w pierwszej kolejności stosunkowo dużą różnorodność form dźwigarów. Belki kompozytowe, będące głównym składnikiem dźwigarów hybrydowych, mają przekrój prostokątny zamknięty lub otwarty, okrągły, typu U, a także trapezowy, zamknięty lub otwarty górą. Te pierwsze były najczęściej stosowane do małych mostów płytowych, z kolei te ostatnie do stosunkowo dużych (jak na kompozyty) mostów belkowych. Belki prostokątne o małym przekroju były wykonywane metodą pultruzji, jednakże wraz ze zwiększaniem ich wymiarów stosowano do ich produkcji metodę układania ręcznego, następnie zautomatyzowaną metodę nawijania, a ostatnio metodę infuzji VARTM. Większość przedstawionych dźwigarów wykonano z kompozytu na bazie włókien szklanych (GFRP) ze względu na ich zdecydowanie niższą cenę w stosunku do kompozytów z włókien węglowych (CFRP). Dla zwiększenia sztywności dźwigara, a także dla uzyskania specyficznej ,pseudo-plastyczności” początkowo kompozyt węglowy CFRP stosowano w postaci taśm wzmacniających, przyklejanych do rozciąganych pasów belki. W najnowszych rozwiązaniach ten sam efekt uzyskiwany jest przez zastosowanie w pasach dolnych kompozytu hybrydowego GFRP/CFRP, który powstaje w jednym procesie infuzji wraz z pozostałymi elementami dźwigara.

Beton, stosowany dla zwiększenia sztywności i obniżenia kosztu dźwigarów, pełni zazwyczaj rolę pasa ściskanego, a jednocześnie płyty pomostu obiektu mostowego. Jednakże w dwóch przypadkach - dźwigarów typu CFFT i HCB - beton wykorzystano także wewnątrz konstrukcji kompozytowej dźwigara, dla przeniesienia kierunkowych sił wewnętrznych i zapewnienia lokalnej stateczności kompozytu. Stosuje się głównie beton zwykły, lecz są także przykłady z be- 
tonem lekkim, a w przypadku dźwigarów CFFT - z betonem samozagęszczalnym. Płyty betonowe zbroi się siatkami prętów stalowych lub prętów kompozytowych GFRP. Dominującą formą zespolenia płyty betonowej i belki kompozytowej w dźwigarach hybrydowych są sworznie stalowe, osadzane w różny sposób w kompozycie pasów górnych. W tym zakresie widoczne jest stałe poszukiwanie efektywnych i niezawodnych rozwiązań. Wśród nich można wymienić poziome łączniki rurowe w belkach U, sworznie kompozytowe, kształtowniki kompozytowe klejone do pasów belki czy nawet bezpośrednie klejenie betonu do kompozytu, bez stosowania łączników mechanicznych.

Współcześnie dźwigary hybrydowe są stosowane do mostów drogowych w zakresie rozpiętości 10 - $20 \mathrm{~m}$. Dla krótszych przęseł - do $15 \mathrm{~m}$ - stosuje się zazwyczaj konstrukcję płytową z kształtowników prostokątnych, klejonych wzajemnie i przykrywanych wspólną płytą betonową, zespoloną z belkami. Wysokość konstrukcyjna takiego przęsła płytowego wynosi ok. 0,6 m (smukłość 1/25). Dla większych rozpietości stosuje się przęsła belkowe, wykonane najczęściej z belek typu U o wysokości konstrukcyjnej około 1,0 m (smukłość 1/20). Najdłuższe przęsła ponad $20 \mathrm{~m}$ wykonuje się z dźwigarów skrzynkowych (trapezowych), które wraz z płytą betonową mają wysokość rzędu $1,20 \mathrm{~m}$. W przypadku bardzo małej dostępnej wysokości konstrukcyjnej (poniżej $0,5 \mathrm{~m}$ ) formą dźwigara hybrydowego, który może być zastosowany w całym wymienionym zakresie rozpiętości, jest dźwigar rurowy CFFT.

Liczba dźwigarów oraz ich rozstaw poprzeczny w typowej szerokości przęśle belkowego mostu drogowego jest uzależniony od rodzaju dźwigarów. W przypadku krótszych mostów (do $15 \mathrm{~m}$ ) stosowano stosunkowo dużą liczbę dźwigarów w małym rozstawie poprzecznym $(0,7-0,9 \mathrm{~m})$. W większych mostach, gdzie stosowano dźwigary trapezowe lub typu U, ich liczba wynosiła 3 lub 4, a rozstaw poprzeczny ok. 2,5 m. Żelbetowa płyta pomostu, zespolona z dźwigarami, pełni w takich przęsłach jeszcze jedną ważną funkcję - jest stężeniem poprzecznym dźwigarów. W opisanych rozwiązaniach konstrukcyjnych, z wyjątkiem betonowych lub kompozytowych poprzecznic podporowych, nie stosowano żadnych dodatkowych stężeń poprzecznych na długości przęsła.

\section{Podsumowanie}

Mosty hybrydowe, w których w sposób celowy połączono zalety kompozytów FRP oraz betonu, należą współcześnie do najszybciej rozwijających się typów konstrukcji mostowych. Powodem tego jest skuteczne połączenie powszechnie już znanych zalet kompozytów FRP jak trwałość, wytrzymałość, lekkość, z zaletami betonu, tj. sztywność, niski koszt oraz „pseudo-plastyczny” sposób zniszczenia przy ściskaniu. Inteligentne połączenie tych zalet w projektach mostów hybrydowych już wkrótce może spowodować, że ten rodzaj drogowych przęseł mostowych zdobędzie dużą popularność w ciągu dróg publicznych krajów wysoko rozwiniętych. Jednakże do pełnego przekonania admini- 
stracji publicznej o zasadności stosowania tego typu konstrukcji jest konieczna kontynuacja badań naukowych nad poszczególnymi rodzajami dźwigarów hybrydowych oraz zachowaniem się mostów z nich wykonanych podczas eksploatacji. W przyszłych badaniach powinny zostać podjęte i dokładniej wyjaśnione m.in.: następujące problemy:

- nośność, trwałość i mechanizm zniszczenia zespolenia pomiędzy kompozytem a betonem (mechaniczne, klejowe);

- zachowanie dźwigarów hybrydowych w czasie (zmęczenie, pełzanie, oddziaływanie środowiska);

- zachowanie dźwigarów hybrydowych pod obciążeniem/oddziaływaniem wyjątkowym (uderzenie, pożar);

- skuteczne i efektywne metody NDT i SHM dla mostów hybrydowych;

- wytyczne i normy projektowe.

Praca powstała w ramach projektu pn.: „COMBRIDGE - Innowacyjny most drogowy z kompozytów FRP”. Projekt jest realizowany w ramach przedsięwzięcia pilotażowego pn.: Wsparcie badań naukowych i prac rozwojowych $w$ skali demonstracyjnej DEMONSTRATOR+ pt.: (umowa nr UOD-DEM-1-041-/001) oraz jest współfinansowany przez Narodowe Centrum Badań i Rozwoju.

\section{Literatura}

[1] Hollaway L.C., Head P.R.: Advanced polymer composites and polymers in the civil infrastructure. Elsevier, Oxford, 2001.

[2] Zoghi M. (ed.): The International Handbook of FRP Composites in Civil Engineering. CRC Press, Taylor \& Francis Group LLC, Boca Raton 2014.

[3] Cheng L., Karbhari V.M.: New bridge systems using FRP composites and concrete: a state-of-the-art review. Progress in Structural Engineering and Materials, Vol.8, No. 4, 2006, pp. 143-154.

[4] Yang L.: Research status of FRP-concrete composite beam/bridge deck systems. Applied Mechanics and Materials, Vols. 587-589, 2014, pp. 1424-1429.

[5] Triantafillou T.C., Meier U.: Innovative design of FRP combined with concrete. Proceedings of the First International Conference on Advanced Composite Materials in Bridges and Structures (ACMBS), Sherbrook, Quebec, Canada, 1992, pp.491-499.

[6] Deskovic N., Meier U., Triantafillou T.: Innovative design of FRP combined with concrete: long-term behaviour. Journal of Structural Engineering, Vol.121, No.7, 1995, pp. 1079-1089.

[7] Deskovic N., Triantafillou T., Meier U.: Innovative design of FRP combined with concrete: short-term behaviour. Journal of Structural Engineering, Vol.121, No.7, 1995, pp. 1069-1078.

[8] Van Erp G.M. Design and analysis of fibre composite beams for civil engineering applications. Proceedings of the 1st ACUN International Composites Conference, Composites: Innovations and Structural Applications. Sydney, Australia, 1999, pp.229-238. 
[9] Canning L., Hollaway L., Thorne A. M.: Manufacture, testing and numerical analysis of an innovative polymer composite/concrete structural unit. Proceedings of the ICE - Structures and Buildings, Vol.134, No.3, 1999, pp. $231-241$.

[10] Fam A., Skutezky T.: Composite T-beams using reduced-scale rectangular FRP tubes and concrete slabs. Journal of Composites for Construction, Vol.10, No.2, 2006, pp.172-181.

[11] Hulatt J., Hollaway L., Thorne A.: Short term testing of hybrid T beam made of new prepreg material. Journal of Composites for Construction, Vol.7, No.2, 2003, pp.35-144.

[12] Ribeiro M.C.S., Tavares C.M.L., Ferreira A.J.M., Marques A.T.: Static flexural performance of GFRP-polymer concrete hybrid beams. Proceedings of the International Conference on FRP Composites in Civil Engineering. J. G. Teng, Editor, Elsevier Science Ltd., New York, 2001, pp. 1355-1362.

[13] Elmahdy A., El-Hacha R., Shrive N.: Flexural behaviour of hybrid composite girders in bridge construction. Proceedings of the Fourth International Conference on FRP Composites in Civil Engineering (CICE2008), Zurich, Switzerland, 2008.

[14] El-Hacha R., Chen D.: Behaviour of hybrid FRP-UHPC beams subjected to static flexural loading. Composites Part B: Engineering, Vol.43, No.2, 2012, pp.582-593.

[15] Chakrabortty A., Khennane A., Kayali O., Morozov E.: Performance of outside filament-wound hybrid FRP-concrete beams. Composites Part B: Engineering, Vol.42, No.4, 2011, pp. 907-915.

[16] Zhao L., Karbhari V.M.: Investigation of stress states and failure mechanisms of a cellular FRP composite bridge deck system. Proceedings of the 16th Annual Technical Conference, American Society for Composites, Blacksburgh, Virginia, 2001, paper No.201, p. 12.

[17] Kitane Y., Aref A., Lee, G.: Static and fatigue testing of hybrid fiber-reinforced polymer-concrete bridge superstructure. Journal of Composites for Construction, Vol.8, No.2, 2004, pp. 182-190.

[18] Ziehl P., Engelhardt M., Fowler T., Ulloa F., Medlock R., Schell E.: Design and field evaluation of hybrid FRP/reinforced concrete superstructure system. Journal of Bridge Engineering, Vol.14, No.5, 2009, pp.309-318.

[19] Hillman J.R.: Investigation of a hybrid-composite beam system. Final Report for High-Speed Rail IDEA Project 23. Transportation Research Board, August 2003.

[20] Gutiérrez E., Primi S., Mieres J.M., Calvo I.: Structural testing of a vehicular carbon fiber bridge: quasi-static and short-term behaviour. Journal of Bridge Engineering, Vol. 13, No. 3, 2008, pp. 271-281.

[21] Vicaria J.D.J, Diaz D.F., Paulotto C., Bansal A.: An application of the FRP girder bridge technology to cope with logistic difficulties. 37th IABSE Symposium Report, Madrid, 2014 pp.2200-2206.

\section{SHAPING OF HYBRID BRIDGE GIRDERS MADE OF FRP COMPOSITE AND CONCRETE}

\section{S u m m a r y}

Despite many advantages in comparison to conventional building materials, the contemporary development of FRP composites in bridge engineering is limited because of the high initial 
cost and the reported lack of stiffness. In order to reduce these limitations, since more than 20 years the hybrid (mixed) solutions, connecting FRP composites with conventional materials (mainly concrete), have been developed. The optimization of hybrid structure based on properties of particular component materials, aims the economic efficiency, without losing lightness and easiness of FRP composite bridge construction. The evolution in shaping of hybrid bridge girders for more than 20 years have been presented in the paper. The basic rules of hybrid girder shaping and the further research, needed for development of these innovative, advanced and sustainable bridge solutions, have been also described.

Keywords: hybrid bridge girder, GFRP composite, concrete deck slab, road bridge, shaping

Przestano do redakcji: 3.12 .2015 r.

Przyjęto do druku: 1.03.2016 r.

DOI: $10.7862 /$ rb.2016.132 